\title{
Pengaruh pemberian ekstrak jamur merang (volvariella volvacea) terhadap kadar kolesterol total, enzim Ippla2 dan mda darah
}

\author{
Amelia Eka Damayanty ${ }^{1}$, Lisyani. B. Suromo², Kisdjamiatun ${ }^{2}$
}

\begin{abstract}
Background: Consumption of high-fat diet (HFD) is increasing blood total cholesterol, LpPLA 2 enzyme and MDA level which is a cause of atherosclerosis that should be controlled by antioxidants. Paddy straw mushroom (Volvariella v.) extract has an antioxidant compounds. This research proves the effect of Volvariella v. extract on blood total cholesterol (TC), LpPLA 2 enzyme and MDA level, and proves correlation between TC with LPPLA 2 enzyme and MDA level.

Methods: A randomized post test only control group design to twenty four of 8-10 weeks old male Rattus novergicus Wistar strain with 180-200 gram were divided into four group; K1 with standard diet, K2 with HFD, each X1 and X2 with HFD+Volvariella v. extract $500 \mathrm{mg} / \mathrm{kg} . \mathrm{bwt} /$ day and $1000 \mathrm{mg} / \mathrm{kg} . \mathrm{bwt} /$ day. All treatments for 56 days. TC levels assesed by enzymatic colorimetric test method, LpPLA 2 enzyme with ELISA method and MDA with TBARs method. Data were analyzed by one way Anova, LSD post hoc and Pearson's correlation.

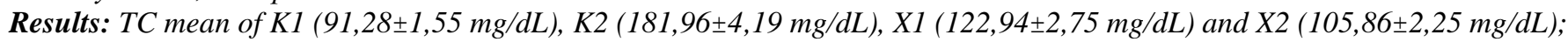

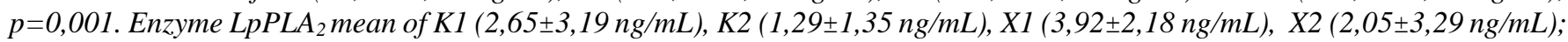
$p=0,385$ and blood MDA mean of $K 1(1,17 \pm 0,12 \mathrm{nmol} / \mathrm{mL}), K 2(5,75 \pm 0,21 \mathrm{nmol} / \mathrm{mL}), X 1(2,96 \pm 0,91 \mathrm{nmol} / \mathrm{mL})$ and X2 $(1,77 \pm 0,92 \mathrm{nmol} / \mathrm{mL}) ; p=0,001$. Correlation between TC and LpPLA $A_{2}$ enzyme was shown by X1 group $(p=0,042 ; r=-0,827)$. Conclusion:Volvariella v. extract decreased blood total cholesterol and MDA level significantly, did not significant to LpPLA

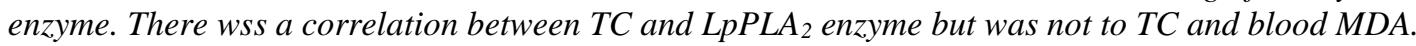

Key: High fat diet; total kolesterol; LpPLA 2 enzymes; MDA; Volvariella v. extract

Latar belakang: Konsumsi diet tinggi lemak (DTL) dapat meningkatkan kadar kolesterol total, enzim LpPLA 2 dan MDA darah yang merupakan penyebab aterosklerosis yang dapat dikendalikan oleh antioksidan. Ekstrak jamur merang (EJM) memiliki senyawa antioksidan. Penelitian ini membuktikan pengaruh pemberian ekstrak jamur merang terhadap kadar kolesterol total (TC), enzim $L p P L A_{2}, M D A$ darah dan korelasi antara TC dengan enzim $L p P L A_{2}, M D A$ darah.

Metode penelitian: Randomized post test only control group pada 24 ekor tikus Rattus novergicus galur Wistar jantan usia 810 minggu berat 180-200 gram, dibagi 4 kelompok yaitu K1 (kontrol negatif) dengan diet standar, K2 (kontrol positif) dengan DTL, X1 dan X2 masing-masing DTL+EJM dosis $500 \mathrm{mg} / \mathrm{kgBB} /$ hari dan dosis $1000 \mathrm{mg} / \mathrm{kgBB} / \mathrm{hari}$. Semua perlakuan dilakukan selama 56 hari. Kadar TC diperiksa dengan metode enzymatic colorimetric test, enzim LpPLA 2 dengan metode ELISA dan MDA dengan metode TBARS. Analisis data dengan one way Anova, post hoc LSD dan korelasi Pearson.

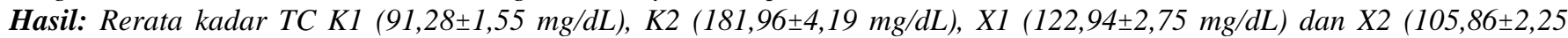
$\mathrm{mg} / \mathrm{dL}) ; p=0,001$. Rerata kadar enzim LpPLA $\mathrm{K}_{2}(2,65 \pm 3,19 \mathrm{ng} / \mathrm{mL}), \mathrm{K} 2(1,29 \pm 1,35 \mathrm{ng} / \mathrm{mL}), \mathrm{X1}(3,92 \pm 2,18 \mathrm{ng} / \mathrm{mL}) \mathrm{dan} \mathrm{X2}$ $(2,05 \pm 3,29 \mathrm{ng} / \mathrm{mL}) ; p=0,385$. Rerata kadar MDA darah $\mathrm{K1}(1,17 \pm 0,12 \mathrm{nmol} / \mathrm{mL}), \mathrm{K} 2(5,75 \pm 0,21 \mathrm{nmol} / \mathrm{mL}), \mathrm{X1}(2,96 \pm 0,91$

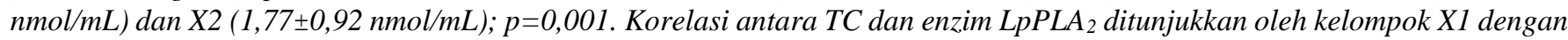
$p=0,042(r=-0,827)$.

Simpulan: EJM menurunkan kadar kolesterol total dan MDA darah secara signifikan, namun tidak menurunkan kadar enzim

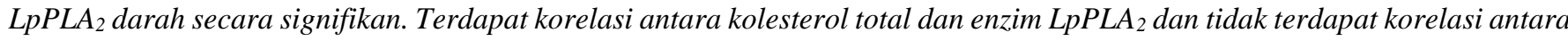
kolesterol total dan MDA darah.

Kata Kunci: Diet tinggi lemak; kolesterol total; enzim LPPLA 2 ; MDA; ekstrak jamur merang

\section{PENDAHULUAN}

Aterosklerosis masih menjadi penyebab masalah kesehatan di dunia, terutama penyakit kardiovaskular dan stroke, dimana prevalensinya terus meningkat pada negara maju dan sedang berkembang.WHO memperkirakan 17,3 juta orang meninggal karena penyakit kardiovaskular pada tahun 2008, dimana 7,3 juta orang meninggal karena penyakit jantung koroner (PJK) dan 6,2 juta orang meninggal karena stroke. Perkiraan pada tahun 2030 kematian

\footnotetext{
1. Fakultas Kedokteran, Universitas Islam Sumatera Utara

2. Fakultas Kedokteran, Universitas Diponegoro
}

akibat penyakit kardiovaskular akan meningkat mencapai 23,3 juta jiwa, terutama yang disebabkan oleh PJK dan stroke. ${ }^{1}$ Salah satu penyebab PJK dan stroke adalah adanya penimbunan lipid dan jaringan fibrosa pada sebagian atau total pembuluh darah sehingga secara progresif mempersempit lumen pembuluh darah. Penyempitan lumen menyebabkan resistensi terhadap aliran darah meningkat dan membahayakan aliran darah ke jantung dan otak. ${ }^{2}$

Lipid plasma yaitu kolesterol, trigliserida, fosfolipid, dan asam lemak bebas yang berasal dari makanan (eksogen) dan dari sintesis lemak (endogen). Lipid tidak larut dalam plasma, tetapi lipid terikat pada 
protein sebagai mekanisme transpor dalam serum. ${ }^{3}$ Istilah hiperlipidemia menyatakan peningkatan kolesterol serum di atas batas normal. Salah satu konsekuensi hiperlipidemia yang paling penting (menurut WHO) adalah peningkatan kolesterol serum, yang terutama mencerminkan kolesterol lipoprotein serum densitas rendah (LDL-C), dimana terdapat 60\%$70 \%$ kolesterol terikat pada LDL yang merupakan faktor predisposisi terjadinya ateroma. ${ }^{3}$

Petanda inflamasi pada aterosklerosis yang menjadi fokus baru-baru ini adalah enzim lipoproteinassociated phospholipase $A_{2}\left(\mathrm{LpPLA}_{2}\right)$ plasma dapat memprediksi kejadian penyakit kardiovaskular di masa depan dan berhubungan dengan faktor risiko klasik aterosklerosis, ${ }^{4}$ seperti hiperkolesterol, ${ }^{5}$ diabetes, ${ }^{6,7}$ hipertensi, ${ }^{8}$ dan sindrom metabolik. ${ }^{6,9}$ Enzim LpPLA $_{2}$ dengan nama lain platelet activating factor asethilhydrolase (PAF-AH) merupakan enzim yang dihasilkan dan disekresikan oleh makrofag sebagai respon terhadap pembentukan lipid peroksida dan peroksida fosfokolin, dimana dalam darah terikat pada apoB dari LDL, dan dalam bentuk tidak aktif. Enzim LpPLA $_{2}$ merupakan petanda non konvensional yang banyak ditemukan dalam serum yang berkaitan erat dengan proses aterogenesis. ${ }^{10}$

Pemberian pakan tinggi lemak akan menimbulkan 3 faktor risiko aterosklerosis yaitu meningkatnya metabolisme lipid, stress oksidatif dan inflamasi. Kadar LDL berpengaruh pada kadar malondialdehyde (MDA), hal ini disebabkan karena senyawa prekursor pembentukan MDA adalah asam arakidonat yang banyak terdapat pada lapisan fosfolipid lapisan luar LDL. ${ }^{11}$ Demikian juga faktor penyebab terjadinya oksidasi asam arakidonat di dalam lipoprotein menjadi MDA dalam serum adalah stress oksidatif yang juga dapat distimulasi oleh kadar LDL yang meningkat. ${ }^{12}$

Jamur pangan telah terbukti mengandung antioksidan yang dapat menghambat stress oksidatif. Volvariella volvacea atau jamur merang merupakan salah satu tanaman pangan yang berkhasiat obat. Kandungan utama jamur merang adalah air, dan mengandung zat gizi makro dan mikro yang cukup tinggi. Jamur merang juga merupakan sumber yang baik dari polipeptida, terpen, dan steroid dan senyawa fenolik seperti flavonoid, asam fenolik, dan tanin yang berkontribusi terhadap kapasitas antioksidan yang tinggi. ${ }^{13,14,15}$

\section{BAHAN DAN METODE}

\section{Subjek}

Dalam penelitian ini subjek yang digunakan adalah hewan coba tikus putih Rattus novergicus strain Wistar jantan berusia 8-12 minggu dengan berat badan ratarata 180-200 gram. Hewan coba berjumlah 24 ekor tikus yang diperoleh dari Laboratorium Gizi Pusat Studi Pangan dan Gizi PAU UGM Yogyakarta.

\section{Desain Penelitian}

Penelitian ini menggunakan desain true experimental dengan rancangan randomized post test only control group design. 24 ekor tikus dibagi menjadi 4 kelompok dengan masing-masing kelompok berjumlah 6 ekor tikus. Kelompok K1 mendapat diet standar, K2 mendapat diet tinggi lemak, X1 mendapat diet tinggi lemak dan ekstrak jamur merang $500 \mathrm{mg} / \mathrm{kgBB} / \mathrm{hari}$ dan X2 mendapat diet tinggi lemak dan ekstrak jamur merang $1000 \mathrm{mg} / \mathrm{kgBB} / \mathrm{hari}$. Seluruh perlakuan diberikan selama 8 minggu (56 hari) dan pengambilan darah hewan coba dilakukan pada hari ke 57.

Pemeriksaan kadar kolesterol total dilakukan dengan menggunakan metode enzymatic colorimetric test. Sementara itu, pemeriksaan kadar enzim LpPLA2 dilakukan dengan menggunakan metode ELISA dan kadar MDA darah menggunakan metode TBARs. Dilakukan uji normalitas dengan menggunakan Shapiro Wilk $(\mathrm{n}<50)$. Sementara itu, untuk data yang berdistribusi normal dan homogen dilakukan uji one way anova untuk kemudian dilakukan uji post hoc untuk melihat perbedaan masing-masing kelompok. Uji korelasi Pearson digunakan untuk menganalisis hubungan antar variable pada masing-masing kelompok.

\section{HASIL}

Kadar Kolesterol Total, Enzim LpPLA 2 dan MDA darah hewan coba setelah perlakuan

Rerata kadar kolesterol total, enzim LpPLA 2 dan MDA darah hewan coba ditunjukkan pada tabel 1.

Tabel 1. Rerata kadar kolesterol total, enzim $\mathrm{LpPLA}_{2}$ dan MDA darah hewan coba setelah perlakuan

\begin{tabular}{cccc}
\hline Kelompok & $\begin{array}{c}\text { Rerata Kadar } \\
\text { kolesterol total darah } \\
(\mathbf{m g} / \mathbf{d L})\end{array}$ & $\begin{array}{c}\text { Rerata Kadar enzim } \\
\mathbf{L P P L A} \text { darah }(\mathbf{n g} / \mathbf{m L})\end{array}$ & $\begin{array}{c}\text { Rerata Kadar MDA } \\
\text { darah }(\mathbf{n m o l} / \mathbf{m L})\end{array}$ \\
\hline $\mathrm{K} 1$ & $91,28 \pm 1,55$ & $2,65 \pm 3,19$ & $1,17 \pm 0,12$ \\
$\mathrm{~K} 2$ & $181,96 \pm 4,19$ & $1,29 \pm 1,35$ & $5,75 \pm 0,21$ \\
$\mathrm{X} 1$ & $122,94 \pm 2,75$ & $3,92 \pm 2,18$ & $2,96 \pm 0,91$ \\
$\mathrm{X} 2$ & $105,86 \pm 2,25$ & $2,05 \pm 3,29$ & $1,77 \pm 0,92$ \\
$P$ & 0,001 & 0,385 & 0,001 \\
\hline
\end{tabular}




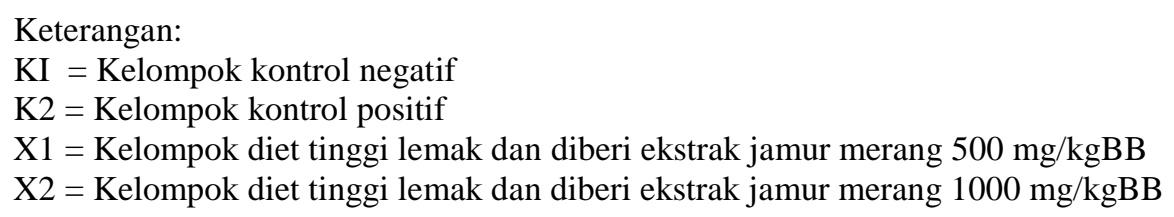

Tabel 1 menunjukkan bahwa kelompok K2 memiliki kadar kolesterol total yang paling tinggi dan kadar enzim LpPLA 2 yang paling rendah dibandingkan kelompok K1, X1 dan X2. Sementara itu, kelompok X1 dan X2 memiliki kadar MDA darah yang lebih rendah dibandingkan kelompok K2 masing-masing 2,96 $\pm 0,91$

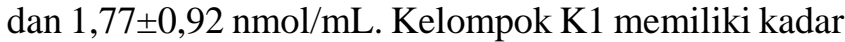
MDA darah yang paling rendah yaitu 1,77 $\pm 0,12$
nmol/mL sementara Kelompok K2 memiliki kadar MDA darah yang paling tinggi yaitu 5,75 \pm $0,21(\mathrm{nmol} / \mathrm{mL})$.

\section{Korelasi Kadar Kolesterol Total dengan Enzim LpPLA 2 dan MDA Darah}

Korelasi kadar kolesterol total dengan enzim $\mathrm{LpPLA}_{2 \text { dan }}$ MDA darah ditunjukkan pada tabel 2.

Tabel 2. Hasil Uji Korelasi Pearson

\begin{tabular}{|c|c|c|c|c|}
\hline \multirow{3}{*}{ Kelompok } & \multicolumn{4}{|c|}{ Kolesterol total } \\
\hline & \multicolumn{2}{|c|}{ Enzim LpPLA2 } & \multicolumn{2}{|c|}{ MDA } \\
\hline & $p$ & $\mathbf{r}$ & $p$ & $\mathbf{r}$ \\
\hline K1 & 0,625 & $-0,256$ & 0,996 & $-0,003$ \\
\hline K2 & 0,751 & $-0,167$ & 0,056 & 0,801 \\
\hline X1 & 0,042 & - 0,827 & 0,125 & 0,696 \\
\hline X2 & 0,270 & 0,339 & 0,917 & 0,056 \\
\hline
\end{tabular}

Keterangan:

$\mathrm{KI}=$ Kelompok kontrol negatif

$\mathrm{K} 2$ = Kelompok kontrol positif

$\mathrm{X} 1$ = Kelompok diet tinggi lemak dan diberi ekstrak jamur merang $500 \mathrm{mg} / \mathrm{kgBB}$

$\mathrm{X} 2=$ Kelompok diet tinggi lemak dan diberi ekstrak jamur merang $1000 \mathrm{mg} / \mathrm{kgBB}$

Korelasi antara kolesterol total dengan enzim LpPLA $_{2}$ darah yang ditunjukkan kelompok X1 merupakan korelasi kuat negatif yang artinya apabila kolesterol total meningkat maka enzim LpPLA 2 akan menurun. Tidak ada korelasi antara kolesterol total dengan MDA darah pada semua kelompok. Secara keseluruhan ekstrak jamur merang dengan dosis 1000 $\mathrm{mg} / \mathrm{kgBB} / \mathrm{hari}$ pada tikus Wistar yang diberi diet tinggi lemak memiliki kadar kolesterol total, enzim LpPLA $_{2}$ dan MDA darah yang lebih rendah dibandingkan dosis $500 \mathrm{mg} / \mathrm{kgBB} / \mathrm{hari}$ yang ditunjukkan oleh seluruh kelompok X2 pada semua variabel.

\section{PEMBAHASAN}

Kelompok K2 memiliki kadar kolesterol total yang paling tinggi karena kelompok ini mendapat diet tinggi lemak sesuai dengan penelitian sebelumnya. ${ }^{16,17,18}$ Kelompok yang mendapat EJM memiliki kadar kolesterol lebih rendah dibandingkan kontrol positif, hal ini sesuai dengan penelitian sebelumnya. ${ }^{19}$ Penurunan kadar kolesterol total darah ini antara lain disebabkan kandungan serat yang tinggi pada jamur merang. Sejalan dengan penelitian terdahulu bahwa serat yang terdapat pada jamur merang antara lain adalah polisakarida $\beta$-glukan yang mampu menurunkan kadar kolesterol darah. ${ }^{19,20,21}$ Beberapa mekanisme serat terhadap metabolisme lemak diantaranya adalah menghambat reaksi enzim lipase gastrointestin seperti enzim lipase pankreas, selain itu serat makanan akan menghalangi siklus enterohepatik (reabsorpsi empedu dalam usus ke hati) dengan kemampuannya menjebak micelles yang mengandung asamempedu dalam usus dengan viskositasnya dan mengeluarkannya dari ikatan dengan transporter membran luminal epitelium intestinal sehingga menurunkan absorpsi dan reabsorpsi lemak termasuk kolesterol dan asam lemak sehingga meningkatkan pengeluarannya pada feses ${ }^{22,23}$ hasilnya akan terjadi peningkatan konversi kolesterol menjadi asam empedu oleh hati. ${ }^{24}$ Pada jamur merang belum ada penelitian mengenai kandungan senyawa aktif yang dapat menurunkan kadar kolesterol darah, namun pada jenis jamur lain yaitu jamur tiram ditemukan adanya senyawa statin yaitu lovastatin yang dapat menurunkan kadar kolesterol darah. Mekanisme penurunan kolesterol dan lipid darah oleh statin meliputi penghambatan enzim pensintesis kolesterol, peningkatan ekskresi kolesterol, dan peningkatan ekskresi garam empedu. Statin merupakan molekul 
yang memiliki kemiripan struktur dengan kolesterol, sehingga mampu menjadi inhibitor aktivitas enzim. ${ }^{24}$

Kemungkinan lain yang dapat menurunkan kadar kolesterol total darah adalah kandungan antioksidan pada jamur merang. ${ }^{13,14,15,25,26,27,28}$ Salah satu antioksidan yang terdapat pada jamur merang adalah senyawa fenolik atau amin aromatik yang merupakan antioksidan yang bekerja dengan memutus rantai yang akan memotong perbanyakan reaksi berantai dari senyawa radikal bebas, ${ }^{29,30}$ yang sejalan dengan penelitian lain. ${ }^{31,31,33,34}$

Sementara itu, kelompok K2 memiliki kadar enzim $\mathrm{LpPLA}_{2}$ yang paling rendah, hal ini kemungkinan disebabkan oleh mekanisme kerja antioksidan enzim LpPLA 2 . Kelompok K2 adalah kelompok yang mendapat diet tinggi lemak tanpa terapi dan pemberian diet tinggi lemak secara terus menerus dapat meningkatkan risiko stres oksidatif. Berdasarkan teori, dalam keadaan normal enzim LpPLA $_{2}$ dalam bentuk tidak aktif namun enzim LpPLA ${ }_{2}$ menjadi aktif saat kolesterol LDL mengalami oksidasi dan fosfolipid sebagai bagian terluar dari LDL juga teroksidasi sehingga mengaktifkan enzim LpPLA 2 yang terikat pada reseptor apoB LDL untuk menghidrolisis fosfolipid teroksidasi, hal ini merupakan salah satu mekanisme kerja enzim LpPLA $_{2}$ yang menyerupai mekanisme kerja antioksidan.

Stres oksidatif merupakan salah satu faktor pemicu enzim LpPLA $2 .{ }^{35}$ Semakin tinggi kadar oxLDL maka semakin banyak enzim LpPLA 2 yang menjadi aktif dan menghidrolisis oxLDL, sehingga akan mengurangi kadar enzim LpPLA ${ }_{2}$ dalam bentuk natural dan tidak aktif. kadar enzim LpPLA 2 pada kelompok K2 sebagai kontrol positif lebih rendah dibanding kelompok K1 sebagai kontrol negatif, hal ini tidak sesuai dengan hipotesa dan teori yang ada. Keadaan ini perlu dikaji apakah hipotesis ini berlaku secara in vivo. Salah satu faktor yang menjadi kontroversi seputar LpPLA $_{2}$ adalah kadarnya yang kurang pada model hewan sederhana seperti binatang pengerat dan kelinci dibandingkan dengan pola distribusi LpPLA $_{2}$ dan lipoprotein pada manusia, dimana pada manusia enzim LpPLA $_{2}$ terutama berikatan dengan LDL, sedangkan pada hewan ini enzim $\mathrm{LpPLA}_{2}$ terutama berikatan dengan HDL. ${ }^{36}$ Selain apoB, distribusi enzim $\mathrm{LpPLA}_{2}$ antara LDL dan HDL dapat dipengaruhi oleh ketersediaan lipoprotein(a) saat kadar lipoprotein plasma melebihi $30 \mathrm{mg} / \mathrm{dl} .{ }^{35}$

Kemungkinan ada mekanisme lain yang menyebabkan peningkatan kadar enzim LpPLA 2 pada kelompok X1 setelah mendapat EJM. Perlu pengkajian yang lebih lanjut terhadap kandungan senyawa aktif EJM, tetapi tidak menutup kemungkinan bahwa EJM mengandung senyawa statin seperti lovastatin pada jamur tiram. Penelitian lain menunjukkan pemberian statin menginduksi peningkatan aktifitas HDL-LpPLA 2 dan menurunkan LDL-LpPLA $2 .{ }^{37}$ Beberapa studi yang memberi terapi obat-obat statin pada pasien dengan PJK juga menunjukkan peningkatan aktifitas HDLLpPLA $_{2}$ dan penurunan aktifitas LDL-LpPLA $2,{ }^{38}$ sehingga kadar LpPLA 2 yang meninggi pada kelompok $\mathrm{X} 1$ tidak dapat dipastikan apakah itu LpPLA 2 yang terikat pada $\mathrm{HDL}$ atau $\mathrm{LpPLA}_{2}$ yang terikat pada LDL terkait dengan kandungan antioksidan pada EJM yang dapat meningkatkan kadar kolesterol HDL, seperti yang ditunjukkan pada penelitian sebelumnya. ${ }^{32,38,39}$

Kelompok K1 memiliki kadar MDA darah yang paling rendah yaitu $1,77 \pm 0,12 \mathrm{nmol} / \mathrm{mL}$ karena hanya mendapat diet standar sehingga meminimalkan stres oksidatif. Kelompok K2 memiliki kadar MDA darah yang paling tinggi karena kelompok ini mendapat diet tinggi lemak tanpa terapi. Keadaan ini sesuai dengan penelitian sebelumnya dimana kadar MDA darah akan meningkat 2,48 kali lipat pada keadaan hiperlipidemia. ${ }^{40}$

Pemberian diet tinggi lemak dapat menginduksi obesitas, hiperglikemik, peningkatan kadar lipid darah dan jaringan dan inflamasi kronis yang kemudian dapat meningkatkan peroksidasi lipid. ${ }^{41,42}$ yang akan meningkatkan kadar MDA darah. Kelompok X1 dan X2 memiliki kadar MDA darah yang lebih rendah dibandingkan kelompok K2 masingmasing 2,96 $\pm 0,91$ dan $1,77 \pm 0,92$. Hal ini menunjukkan bahwa pemberian EJM berasosiasi terhadap penurunan kadar MDA darah dan peningkatan dosis EJM berasosiasi dengan penurunan kadar MDA darah. Hal ini sejalan dengan penelitian sebelumnya dimana subfraksi dari ekstrak metanol maupun etanol jamur merang yang memiliki kandungan total phenolics mampu menghambat peroksidasi lipid secara bermakna. ${ }^{28,43}$ Senyawa fenolik merupakan senyawa antioksidan yang bekerja dengan cara memutus rantai reaksi asam lemak dan radikal bebas. Antioksidan pada jamur merang bekerja secara langsung terhadap reaksi peroksidasi lipid sebagai respon terhadap radikal bebas sehingga berpengaruh terhadap kadar MDA darah. Penelitian sebelumnya juga menyimpulkan pemberian kombinasi serat polisakarida bersama antioksidan polifenol merupakan terapi potensial terhadap obesitas yang berimbas pada penurunan kadar MDA darah. ${ }^{44}$

Korelasi antara kolesterol total dengan enzim $\mathrm{LpPLA}_{2}$ darah yang ditunjukkan kelompok X1 merupakan korelasi kuat negatif yang artinya apabila kolesterol total meningkat maka enzim LpPLA 2 akan menurun. Hal ini kemungkinan disebabkan karena enzim LpPLA ${ }_{2}$ dalam bentuk alami atau tidak aktif yang dapat dibaca oleh kit berkurang jumlahnya di sirkulasi. Kolesterol total yang meningkat akan mencerminkan peningkatan kolesterol LDL, dimana kolesterol LDL sangat mudah teroksidasi oleh radikal bebas. Diet tinggi lemak yang diberikan secara terusmenerus dan status antioksidan yang kurang dalam 
tubuh akan meningkatkan terjadinya stres oksidatif sehingga kolesterol LDL menjadi teroksidasi (oxLDL). OxLDL akan mengaktifkan enzim LpPLA $_{2}$ untuk menghidrolisa fosfolipid dan LDL yang teroksidasi sehingga dapat meminimalkan kadar oxLDL dan menurunkan stres oksidatif, akibatnya kadar enzim LpPLA $_{2}$ alami atau dalam bentuk tidak aktif akan mengalami penurunan.

Tidak ada korelasi antara kolesterol total dengan MDA darah pada semua kelompok. Berdasarkan teori dan studi terdahulu peningkatan kolesterol total seharusnya berkorelasi dengan kadar MDA darah maupun jaringan. ${ }^{40,41,42}$ Pemberian pakan tinggi lemak akan menimbulkan 3 faktor risiko aterosklerosis yaitu meningkatnya metabolisme lipid, stres oksidatif dan inflamasi.Pada penelitian ini tidak memeriksa profil lipid, status stres oksidatif dan status antioksidan hewan coba terkait dengan peningkatan stres oksidatif yang dipicu oleh diet tinggi lemak dan penghambatan stres oksidatif oleh senyawa antioksidan sehingga mempengaruhi korelasi antara kolesterol total dan MDA darah, sehingga memerlukan penelitian lebih lanjut.

Secara keseluruhan ekstrak jamur merang dengan dosis $1000 \mathrm{mg} / \mathrm{kgBB} /$ hari pada tikus Wistar yang diberi diet tinggi lemak memiliki kadar kolesterol total, enzim LpPLA $_{2}$ dan MDA darah yang lebih rendah dibandingkan dosis $500 \mathrm{mg} / \mathrm{kgBB} /$ hari yang ditunjukkan oleh seluruh kelompok X2 pada semua variabel.

Keterbatasan penelitian ini adalah peneliti tidak mengukur profil kolesterol darah dan apoB sebagai binding protein enzim LpPLA $\mathrm{A}_{2}$, kadar oxLDL yang mencerminkan stres oksidatif dan tidak mengukur kadar SOD, katalase ataupun GPx yang berperan sebagai status antioksidan dalam tubuh.

\section{SIMPULAN}

Ekstrak jamur merang menurunkan kadar kolesterol total dan MDA darah secara bermakna, tidak menurunkan kadar enzim LpPLA $_{2}$ darah secara bermakna, terdapat korelasi antara kolesterol total dengan enzim LpPLA $_{2}$ dan tidak terdapat korelasi antara kolesterol total dengan MDA darah.

\section{DAFTAR PUSTAKA}

1. World Health Organisation. Global status report on noncommunicable disease 2012. Geneva Report 2013.

2. Price SA, Wilson LM. Penyakit Aterosklerosis Koroner dalam Patofisiologi. Konsep klinis proses-proses penyakit. Penerjemah: dr. Brahm U. Pendit et al. Edisi 6. Vol. 1; 2005. hal.578-579.
3. Price SA, Wilson LM. Hiperlipidemia. Dalam: Patofisiologi, Konsep klinis proses-proses penyakit. Penerjemah: dr. Brahm U. Pendit et al. Ed. 6. Vol. 1; 2005. hal. 580-2.

4. Kolodgie FD, Burke AP, Skorija KS, Ladich E, Kutys R, Makuria AT, et al. LipoproteinAssociated Phospholipase A2 Protein Expression in the Natural Progression of Human Coronary Atherosclerosis. Arterioscler Thromb Vasc Biol. 2006; 26:2523-29.

5. Gibson M. Effect of Low Density Lipoprotein Apheresis on Lipoprotein Associated Phospholipase A2. Am J Cardiol. 2005; 191:5462.

6. Noto H, Chitkara P, and Raskin P. The Role of Lipoprotrein-Associated Phospholipase A2 in the Metabolic Syndrome and Diabetes. J Diab and the Compli. 2006; 20:343-48.

7. Yang C, Chen H, Huang MT, Raya JL, Yang J, Chen C, et al. Pro-apoptotic Low Density Lipoprotein Subfraction in Type II Diabetes. Atherosclerosis. 2007; 193:283-91.

8. Gorelick PB. Lipoprotein Assocoated phospholipase A2 and Risk of Stroke. Am J Cardiol. 2008; 101:34F-40F.

9. Filippatos TD, Gazi IF, Liberopoulos VG, Elisaf MS, Tselepis AD, et al. The Effect of Orsilat and Fenofibrate, alone or Combination, on Small dense LDL and Lipoprotein-associated Phospholipase A2 in Obese patients with Metabolic syndrome. Atherosclerosis. 2006;17:495-501.

10. Shi Y, Zhang P, Zhang L, Osman H, Mohler ER, Macphee C, et al. Role of Lipoprotein-associated Phospholipase A2 in Leukocyte Activation and Inflammatory Responses. Atherosclerosis. 2007; 191:54-62.

11. Gustone FD. Fatty acid and lipid chemistry. New York: Blackie Academic \& Professional; 1996. p. 81.

12. Halliwell B, Guteridge JMC. Free radicals in biology and medicine. 3th ed. NewYork: Oxford University Press; 1999. Dalam: Sargowo D, Susilowati R, Indra R, Tjokroprawiro A, Widyarti S. Korelasi antara kadar Lp-PLA2 serum dan jaringan aorta dengan jumlah sel busa dalam proses aterogenesis pada tikus wistar. Maj Kardio Ind. 2012; 3.

13. Roy A, Gupta N. Volvariella volvacea: $A$ Macrofungus having nutritional and health potential. Asian J. Pharm Tech. 2014; 4(2):110-3.

14. Hung PV, Nhi NNY. Nutritional composition and antioxidant capacity of several edible mushrooms grown in the Southern Vietnam. Int Food Research J. 2012; 19(2):611-615. 
15. Ramkumar L. Evaluation of nutrients, trace metals and antioxidant activity in Volvariella volvacea (Bull. Ex. Fr.) Sing. Emir J Food Agric. 2012; 24 (2):113-9.

16. Murwani S, Ali M, Muliartha K. Diet aterogenik pada tikus putih (Rattus novergicus strain Wistar) sebagai model hewan aterosklerosis. J Ked Braw. 2006; 22(1).

17. Setianingsih H, Ngesti I, Wibisono. Pembuatan preparat hiperkolesterolemia dalam penelitian sebagai upaya pengembangan teknologi kesehatan dan terapi alternatif. Prosiding seminar nasional. 2013.

18. Susilowati R. Pengaruh akut diet aterogenik terhadap profil lipid dan lipoproteinphospholipase A2.[Penelitian hibah]. Universitas Brawijaya. 2010.

19. Cheung PCK. Plasma and hepatic cholesterol levels and fecal neutral sterol excretion are altered in hamsters fed straw mushroom diets. J Nutr. 1998; 128:1512-16.

20. Cheung P.C.K. Dietary fiber content and composition of some cultivated edible mushroom fruiting bodies and mycelia. J. Agric. Food. Chem. 1996; 44:468-471.

21. Cheung P.C.K. The hypocholesterolemic effect of extracellular polysaccharide from submerged fermentation of mushroom. Nutr. Res. 1996; 16: 1953-1957.

22. Ellegard LA.H. Oat bran rapidly increases bile acid excretion and bile acid synthesis : an ileostomy study. Eur J Clin Nutr. 2007; 61: 93845.

23. Theuwissen E, M.R. Water-soluble dietary fibers and cardiovascular disease-a review. Physiology \& Behavior. 2008; 94(2):285-92.

24. Eva Guillamón A.G.L., Miguel Lozano, Matilde D’Arrigo, and A.V. Mauricio A. Rostagno, José Alfredo Martínez. Edible mushrooms: Role in the prevention of cardiovascular diseases. Fitoterapia. Elsevier. 2010; 81: 715-723.

25. Singdevsachan, Kalava S. Diversity, nutritional composition and medicinal potential of Indian mushrooms. In: A review. Afr J Biotech; Academic Journal. 2014; 13(4):523-45.

26. Preeti A, Sharma S, Aggarwal J. Antioxidant mushroom: A review. Int Researc J Pharm, 2012; 3: 6 .

27. Warintorn R, Boonpisuttinant K, Jantrawut P. Potent in vitro collagen biosynthesis stimulating and antioxidant activities of edible mushroom volvariella volvacea aqueous extract. Int $\mathrm{J}$ Pharmacy and Pharmaceutical Sci, 2014. 6; 2.

28. Cheung LM, Cheung PC, Ooi VEC. Antioxidant activity and total phenolics of edible mushroom extract. Food Chemistry Elsevier, 2003; 81:24955.

29. Murray RK, Granner DK, Mayes PA, Rodwell VW. Lipid yang memiliki makna fisiologis. Dalam: Biokimia Harper. Penerjemah: dr. Andry Hartono DAN. Ed. 25. Appleton \& Lange; 2003. hal. 148-59.

30. Mufidah. Aktivitas Aterosklerosis Ekstrak Terstandar Klika Ongkea (Mezzetia parviflora BECC.) Pada Tikus Wistar Yang Diberi Asupan Kolesterol : Kajian Efek Anti-oksidan dan Antikolesterol terhadap Penghambatan MCP-1 dan Disfungsi Endotel. [Disertasi]. Universitas Hasanuddin. 2011.

31. Moreno D.A., Ilic N., Poulev A., Brasaemle D.L., Fried S.K., Raskin I. Inhibitory Effects of Grape Seed Extract on Lipases. Nutrition. 2003; 19: 876879.

32. Wang Y., Sun C., Lu B., Xie Y., Sun C., An L. Effect of Grape Seed Procyanidin to Fat Deposition of Obese Mice. Acta Agriculturae Boreali-Occidentalis Sinica. 2011;06: 1-5.

33. Sergent T., Vanderstraeten J., Winand J., Baguin P., Schneider Y.J. Phenolic compounds and plant extracts as potential natural anti-obesity substances. Food Chemistry. Elsevier. 2012; 135(1): 68-73.

34. Hussein M.A. and El-Maksoud H.A. Biochemical effects of Resveratrol and Curcumin combination on obese diabetic rats. Molecular and Clinical Pharmacology. 2013; 4(1): 1-10.

35. Alexandro D Tselepis, M.J.C., Inflammation, bioactive lipids and atherosclerosis: A potential roles of a lipoprotein-associated phospholipase A2, platelet activating factor-acetylhydrolase. Atheroscler Supp, 2002: 3 (57-68).

36. Macphee $\mathrm{CH}$, Zalewski A. Role of lipoproteinassociated phospholipase A2 in atherosclerosis and its potential as a therapeutic target. Curent Opinion Pharm. 2006; 6:154-161.

37. Tsimihodimos V, Karabina SP., Tambaki AP, Bairaktari E, Goudevenos JA, and E.M. Chapman MJ, Tselepis AD. Atorvastatin Preferentially Reduces LDL-Associated Platelet-Activating Factor Acetylhydrolase Activity in Dyslipidemias of Type IIA and Type IIB. Arterioscler Thromb Vasc Bio. 2002; 22:306-311.

38. Tsimihodimos V, Tambaki AP, Bairaktari E, Miltiadous G,et al. Altered distribution of PAFacetylhydrolase activity between LDL and HDL as a function of the severity of hypercholesterolemia. J Lipid Res. 2002; 43:256-63.

39. Wang Y., Sun C., Lu B., Xie Y., Sun C., An L. Effect of Grape Seed Procyanidin to Fat Deposition of Obese Mice. Acta Agriculturae Boreali-Occidentalis Sinica. 2011;06: 1-5. 
40. Sargowo D, Susilowati R, Indra R, Tjokroprawiro A, Widyarti S. Korelasi antara kadar Lp-PLA2 serum dan jaringan aorta dengan jumlah sel busa dalam proses aterogenesis pada tikus wistar. Maj Kardio Ind. 2012; 3.

41. Noeman SA, Baalash AA. Biochemical study of oxidative stress markers in the liver, kidney and heart of high fat diet induced obesity in Rats. Diabet \& Met Synd. 2011; 3:17.

42. Yang RL, Hao G, Li Wu, Le GW. Increasing oxidative stress with progressive hyperlipidemia in human: Realtion between malondialdehide and atherogenic index. J Clin Biochem Nutr. 2008; 43:154-8.

43. Cheung LM and Cheung PCK. Mushroom extracts with antioxidant activity against lipid peroxidation. Food Chem. Elsevier. 2005; 89: 403-409.

44. Yan $\mathrm{Xu}$, Min Zhang, Tao $\mathrm{Wu}$, Shengdong Dai, Jinling $\mathrm{Xu}$ and Zhongkai Zhou. The anti obesity effect of green tea polysaccharides, polyphenol and caffeine in rats fed with a high fat diet. Food and Function. 2014; 6: 296-303. 